\title{
Methanobacterium veterum sp. nov., from ancient Siberian permafrost
}

\author{
Kirill V. Krivushin, ${ }^{1}$ Viktoria A. Shcherbakova, ${ }^{2}$ Lada E. Petrovskaya ${ }^{3}$ \\ and Elizaveta M. Rivkina ${ }^{1}$ \\ ${ }^{1}$ Institute of Physicochemical and Biological Problems in Soil Sciences, Russian Academy of \\ Sciences, Pushchino, 142290 Moscow Region, Russian Federation \\ ${ }^{2}$ Skryabin Institute of Biochemistry and Physiology of Microorganisms, Russian Academy of \\ Sciences, Pushchino, 142290 Moscow Region, Russian Federation \\ ${ }^{3}$ Shemyakin and Ovchinnikov Institute of Bioorganic Chemistry, Russian Academy of Sciences, ul. \\ Miklukho-Maklaya, 16/10, 117997 GSP, Moscow V-437, Russian Federation
}

Correspondence

Kirill V. Krivushin krivushin@bk.ru
Low-temperature ecosystems play an essential role in Earth's climate and the balance of greenhouse gases in the atmosphere (Corradi et al., 2005). Arctic permafrost is a natural cryobank of both aerobic (Zvyagintsev, 1985; Gilichinsky et al., 1989; Vorobyova et al., 1997; Vishnivetskaya et al., 2000) and anaerobic (Rivkina et al., 1998; Shcherbakova et al., 2005; Vatsurina et al., 2008) micro-organisms.

To date, a few species of methanogen [Methanococcoides burtonii (Franzmann et al., 1992), Methanogenium frigidum (Franzmann et al., 1997), Methanomethylovorans hollandica (Lomans et al., 1999), Methanobacterium subterraneum (Kotelnikova et al., 1998) and Methanobacterium aarhusense (Shlimon et al., 2004)] have been isolated from modern low-temperature terrestrial ecotopes. Previously, methanogenic archaea affiliated to the genera Methanobacterium and Methanosarcina have been described from Arctic permafrost sediments of different ages (Rivkina et al., 2007). The goal of the present study was to describe novel methanogenic archaea from ancient permafrost sediments.

The GenBank/EMBL/DDBJ accession number for the $16 \mathrm{~S}$ rRNA gene sequence of strain $M K 4^{\top}$ is EF016285.

Micrographs of cells of $M K 4^{\top}$ and graphs showing the effects of temperature, $\mathrm{pH}$ and $\mathrm{NaCl}$ concentration on growth are available as supplementary material with the online version of this paper.
Samples were selected from deep $(28 \mathrm{~m}$ beneath the surface) late-Pliocene permafrost (Kolyma lowland; $70^{\circ}$ $06^{\prime} \mathrm{N} 154^{\circ} 04^{\prime} \mathrm{E}$ ). The age of the sediments (3 million years) was estimated on the basis of palaeomagnetic, palynological and palaeontological analyses (Sher, 1974, 1997; Sher et al., 2005; Virina, 1997; Zazhigin, 1997; Schirrmeister et al., 2002). Climatic and geological evidence suggests that these sediments have remained frozen for at least 3 million years. The native temperature of the permafrost was $-10{ }^{\circ} \mathrm{C}$. Permafrost was sampled aseptically with a fluid-free drilling machine that prevented down-hole contamination (Shi et al., 1997). In the field and during transportation to the laboratory, samples were stored in a thermostatic container at $-10{ }^{\circ} \mathrm{C}$.

An enrichment culture was obtained by adding permafrost samples (approx. $10 \mathrm{~g}$ ) to $60 \mathrm{ml}$ vials with $5 \mathrm{ml}$ anaerobic medium (Hungate, 1969) of the following composition $\left(1^{-1}\right): \mathrm{K}_{2} \mathrm{HPO}_{4}, 0.29 \mathrm{~g} ; \mathrm{KH}_{2} \mathrm{PO}_{4}, 0.29 \mathrm{~g} ; \mathrm{NaCl}, 1.0 \mathrm{~g}$; $\mathrm{MgCl}_{2} \cdot 6 \mathrm{H}_{2} \mathrm{O}, 0.2 \mathrm{~g} ; \mathrm{NH}_{4} \mathrm{Cl}, 1.0 \mathrm{~g} ; \mathrm{CaCl}_{2} \cdot 2 \mathrm{H}_{2} \mathrm{O}, 0.1 \mathrm{~g}$; cysteine hydrochloride, $0.5 \mathrm{~g} ; \mathrm{Na}_{2} \mathrm{~S} .9 \mathrm{H}_{2} \mathrm{O}, 0.5 \mathrm{~g}$; vitamin solution (Balch et al., 1979), $5 \mathrm{ml}$; trace element solution (Balch et al., 1979), $10 \mathrm{ml}$. The medium was adjusted to $\mathrm{pH}$ 7.2-7.4. $\mathrm{H}_{2}$ and $\mathrm{CO}_{2}(4: 1,150 \mathrm{kPa})$ were used as the sole carbon and energy source.

Samples were incubated at 6 and $20{ }^{\circ} \mathrm{C}$. Methane emission dynamics was observed by means of a Pye-Unicam 304 gas-liquid chromatograph with flame-ionization detector 
as described previously (Kotelnikova et al., 1993). Active methanogenesis was detected after 12 months of cultivation at $20{ }^{\circ} \mathrm{C}$. After the methane concentration reached $40 \%$, the entire contents of the flask were transferred into a Balch tube $(25 \mathrm{ml})$ supplied with $5 \mathrm{ml}$ basal medium with a gas mixture of $\mathrm{H}_{2}$ and $\mathrm{CO}_{2}$. Pure cultures were obtained by subsequent 10 -fold dilutions in roll-tubes. Cell morphology was examined using a Lumam I-2 phase-contrast microscope with $90 \times 15$ magnification and a JEM100 electron microscope with ultrathin sections as described by Shcherbakova et al. (2005). The cells were non-motile, curved rods, $2.0-8.0 \mu \mathrm{m}$ long and $0.40-0.45 \mu \mathrm{m}$ wide (Supplementary Fig. S1a, available in IJSEM Online). They stained Gram-negative but contained a complex, multilayered, Gram-positive-type cell wall (Supplementary Fig. S1b). Cells occurred singly and as aggregates in old cultures. Filamentous cells (up to $30 \mu \mathrm{m}$ long) were also frequently observed (not shown).

Methanobacterium bryantii VKM B-1629 ${ }^{\mathrm{T}}$ was used in comparative studies. DSMZ medium 506 (http://www. dsmz.de/microorganisms/medium/pdf/DSMZ_Medium506. pdf) with a few modifications $\left[\mathrm{I}^{-1}\right.$ : sodium acetate trihydrate, $0.05 \mathrm{~g} ;\left(\mathrm{NH}_{4}\right)_{2} \mathrm{SO}_{4}, 0.45 \mathrm{~g} ; \mathrm{K}_{2} \mathrm{HPO}_{4}, 0.29 \mathrm{~g} ; \mathrm{KH}_{2} \mathrm{PO}_{4}, 0.18 \mathrm{~g}$; $\mathrm{MgSO}_{4} \cdot 7 \mathrm{H}_{2} \mathrm{O}, 0.12 \mathrm{~g} ; \mathrm{CaCl}_{2} .2 \mathrm{H}_{2} \mathrm{O}, 0.06 \mathrm{~g} ; \mathrm{NaCl}, 5.0 \mathrm{~g}$; vitamin solution, $10 \mathrm{ml}$; trace element solution, $10 \mathrm{ml}$; resazurin, $0.001 \mathrm{~g}$; cysteine hydrochloride monohydrate, $\left.0.25 \mathrm{~g} ; \mathrm{Na}_{2} \mathrm{~S} .9 \mathrm{H}_{2} \mathrm{O}, 0.25 \mathrm{~g}\right]$ was used for detection of the growth ranges of strain $\mathrm{MK}^{\mathrm{T}}$ and Methanobacterium bryantii $\mathrm{VKM} \mathrm{B}-1629^{\mathrm{T}}$ at different $\mathrm{pH}$, temperature and $\mathrm{NaCl}$ concentrations. The compositions of the vitamin and trace element solutions are available at http://www.dsmz.de/ microorganisms/medium/pdf/DSMZ_Medium141.pdf. All tests were performed twice and confirmed by two transfers. Growth was estimated by measuring the concentration of methane in the gas phase (Powell, 1983). Growth of strain $\mathrm{MK} 4{ }^{\mathrm{T}}$ was observed at $10-46{ }^{\circ} \mathrm{C}$ (optimum $28{ }^{\circ} \mathrm{C}$ ) and Methanobacterium bryantii VKM B- $1629^{\mathrm{T}}$ grew at $20-50{ }^{\circ} \mathrm{C}$ (optimum $37{ }^{\circ} \mathrm{C}$ ) (Supplementary Fig. S2a). Both strains were mesophiles according to the classification of Morita (1975), but strain $\mathrm{MK}^{\mathrm{T}}$ grew over a wider range of temperature. The effect of $\mathrm{pH}$ on growth was measured in basal medium 506 with the addition of sterile $1 \mathrm{M} \mathrm{HCl}, 10 \%$ $(\mathrm{w} / \mathrm{v}) \mathrm{NaHCO}_{3}$ or $8 \%(\mathrm{w} / \mathrm{v}) \mathrm{Na}_{2} \mathrm{CO}_{3}$ solutions to obtain the required final $\mathrm{pH}$. A decrease in the $\mathrm{pH}$ of the medium of no more than $0.2-0.4 \mathrm{pH}$ units was observed at the end of the exponential phase. Strain $\mathrm{MK}^{\mathrm{T}}$ grew at $\mathrm{pH}$ 5.2-9.4 (optimum pH 7.0-7.2), whereas optimum growth of Methanobacterium bryantii VKM B- $1629^{\mathrm{T}}$ was observed at pH 6.9-7.0 (range pH 5.8-8.8) (Supplementary Fig. S2b). The effect of $\mathrm{NaCl}$ was examined in basal medium containing $0.01,0.02,0.03,0.05,0.1,0.2,0.3,0.4$ and $0.5 \mathrm{M} \mathrm{NaCl}$. The strain grew at $\mathrm{NaCl}$ concentrations of $0-0.3 \mathrm{M}$, with optimum growth at $0.05 \mathrm{M} \mathrm{NaCl}$. NaCl concentrations up to $0.35 \mathrm{M}$ did not affect growth of Methanobacterium bryantii VKM B-1629 $9^{\mathrm{T}}$ (Supplementary Fig. S2c). In addition to $\mathrm{H}_{2}$ plus $\mathrm{CO}_{2}$, the following substrates were tested for growth of strain $\mathrm{MK}^{\mathrm{T}}$ and Methanobacterium bryantii VKM
B-1629 ${ }^{\mathrm{T}}$ : formate $(50 \mathrm{mM})$, acetate $(50 \mathrm{mM})$, methanol (50 mM) plus $\mathrm{H}_{2}$, methylamine $(20 \mathrm{mM})$ plus $\mathrm{H}_{2}$, ethanol $(10 \mathrm{mM})$, isopropanol $(10 \mathrm{mM})$, isobutanol $(10 \mathrm{mM})$, methylamine $(20 \mathrm{mM})$ and trimethylamine $(20 \mathrm{mM}) . \mathrm{H}_{2}$ plus $\mathrm{CO}_{2}$ (growth rate $0.026 \mathrm{~h}^{-1}$ ), methanol plus $\mathrm{H}_{2}$ $\left(0.014 \mathrm{~h}^{-1}\right)$ and methylamine plus $\mathrm{H}_{2}\left(0.012 \mathrm{~h}^{-1}\right)$ supported growth and methanogenesis of strain $\mathrm{MK}^{\mathrm{T}}$, while Methanobacterium bryantii VKM B- $1629^{\mathrm{T}}$ grew on $\mathrm{H}_{2}$ plus $\mathrm{CO}_{2}\left(0.031 \mathrm{~h}^{-1}\right)$ and used isobutanol for methane production without visible growth. Although growth of Methanobacterium bryantii VKM B-1629 ${ }^{\mathrm{T}}$ on isopropanol was reported previously (Zellner \& Winter, 1987), it was not observed in the present study. Examination of the effects of the addition of acetate $(1,2,5,10$ and $20 \mathrm{mM})$, yeast extract $\left(0.1\right.$ and $\left.0.5 \mathrm{~g} \mathrm{l}^{-1}\right)$, coenzyme $\mathrm{M}\left(25 \mathrm{mg} \mathrm{l}^{-1}\right)$ and Casamino acids $\left(1 \mathrm{gl}^{-1}\right)$ on growth of strain $\mathrm{MK} 4^{\mathrm{T}}$ showed stimulation of growth by acetate only, at concentrations of 5 and $10 \mathrm{mM}$.

Cells of strain $\mathrm{MK}^{\mathrm{T}}$ from exponentially growing cultures were resistant to lysis by $1 \%$ SDS and distilled water as a hypotonic solution.

Genomic DNA was isolated as described previously (Sambrook et al., 1989). The DNA G+C contents, determined by the thermal denaturation method (four replications) using a Pye-Unicam SP1800 spectrophotometer, were $33.8 \pm 0.3$ and $35.2 \pm 0.3 \mathrm{~mol} \%$ for $\mathrm{MK}^{\mathrm{T}}$ and Methanobacterium bryantii VKM B-1629 ${ }^{\mathrm{T}}$, respectively.

The 16S rRNA gene was amplified by PCR using an Eppendorf Mastercycler Personal Thermal Cycler. The gene was amplified in a $50 \mu \mathrm{l}$ reaction containing $2 \mu \mathrm{l}$ (approx. 1-5 ng) template DNA, $1 \mu \mathrm{l}(20 \mathrm{pmol})$ each primer (Evrogen) and PCR kit reagent (Evrogen). The 16S rRNA gene was amplified with universal primers A8F (5'TCCGGTTGATCCTGCCGG-3') and 1492R (5'-ACGGYTACCTTGTTACGACTT- $\left.3^{\prime}\right)$. The PCR conditions were $94{ }^{\circ} \mathrm{C}$ for $5 \mathrm{~min}$ for primary denaturation followed by 30 cycles of $94{ }^{\circ} \mathrm{C}$ for $45 \mathrm{~s}$ (denaturation), $55{ }^{\circ} \mathrm{C}$ for $45 \mathrm{~s}$ (annealing) and $72{ }^{\circ} \mathrm{C}$ for $90 \mathrm{~s}$ (chain extension) and a final $5 \mathrm{~min}$ chain extension step at $72{ }^{\circ} \mathrm{C}$. The obtained PCR product was purified by electrophoresis in $1 \%$ agarose, excised from the gel and eluted with a MiniElute gel extraction kit (Qiagen). Sequencing reactions were performed using the ABI PRISM BigDye Terminator kit version 3.1 and an ABI PRISM 3100-Avant automatic DNA sequencer according to the protocols provided by the manufacturer. The sequence obtained (1347 bp) was subjected to phylogenetic analyses using MEGA4 (Tamura et al., 2007), and a neighbour-joining tree is shown in Fig. 1.

The isolate was phenotypically similar to other species of the genus Methanobacterium (Table 1). Like Methanobacterium beijingense, Methanobacterium congolense and Methanobacterium alcaliphilum, the cells stained Gram-negative. Along with Methanobacterium subterraneum and Methanobacterium aarhusense, strain $\mathrm{MK}^{\mathrm{T}}$ demonstrated a wide growth temperature range. The most important differences from these and other species of the 


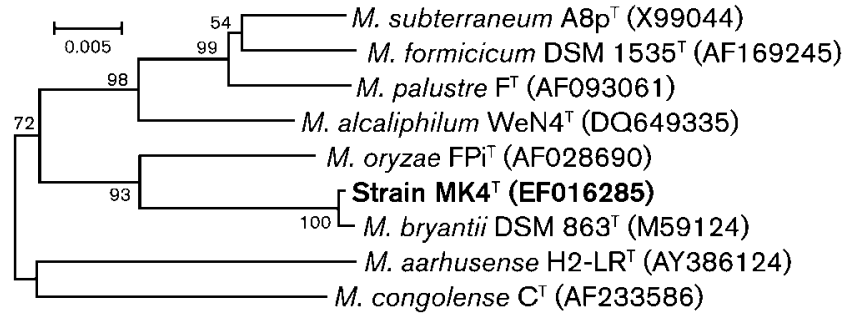

Fig. 1. Phylogenetic dendrogram of $16 \mathrm{~S}$ rRNA gene sequences showing the position of strain $\mathrm{MK} 4^{\top}$ relative to other species of the genus Methanobacterium. Evolutionary history was inferred using the neighbour-joining method (Saitou \& Nei, 1987). The sum of branch lengths is 0.13724225 . Percentages of replicate trees in which the associated taxa clustered together in the bootstrap test (from 1000 replicates) are shown next to the branches (Felsenstein, 1985). The tree is drawn to scale, with branch lengths in the same units as those of the evolutionary distances used to infer the phylogenetic tree. Evolutionary distances were computed using the maximum composite likelihood method (Tamura et al., 2004) and are in units of numbers of base substitutions per site. All positions containing gaps and missing data were eliminated from the dataset (complete deletion option). There was a total of 1259 positions in the final dataset. Bar, 0.005 substitutions per nucleotide position.

genus Methanobacterium with validly published names are its low optimum growth temperature $\left(28{ }^{\circ} \mathrm{C}\right.$;
Supplementary Fig. S2a) and ability to use $\mathrm{H}_{2}$ plus methanol and $\mathrm{H}_{2}$ plus methylamine for growth and methanogenesis. The main substrates for growth of $\mathrm{MK}^{\mathrm{T}}$ were $\mathrm{H}_{2}$ and $\mathrm{CO}_{2}$, as for other Methanobacterium species. Utilization of only $\mathrm{H}_{2}$ plus methanol is typical of Methanosphaera species, and has also been shown for several other methylotrophic methanogens (Müller et al., 1986). Strain $\mathrm{MK}^{\mathrm{T}}$ is the first reported member of the genus Methanobacterium that is capable of utilizing these substrates for growth and methanogenesis. The expanded range of utilizable substrates possibly increases the chances of survival under the nutrientlimited conditions of the permafrost.

Although high 16S rRNA gene sequence similarity was observed between the isolate and Methanobacterium bryantii VKM B- $1629^{\mathrm{T}}(99 \%)$, the results of DNA-DNA hybridization with the thermal reassociation method (De Ley et al., 1970 ) indicated $62 \pm 6 \%$ genomic relatedness (four replications). According to the minimal standards for the description of new taxa of methanogens (Boone \& Whitman, 1988) and based on phylogenetic and phenotypic characters, a novel species of the genus Methanobacterium is proposed, Methanobacterium veterum sp. nov.

\section{Description of Methanobacterium veterum sp. nov.}

Methanobacterium veterum (ve'te.rum. L. gen. pl. n. veterum of the old, of old things, of antiquity, referring to the isolation of the type strain from ancient permafrost).

Table 1. Characteristics of the type strains of Methanobacterium species

Strains: 1, MK4 $4^{\mathrm{T}}$; 2, M. bryantii DSM $863^{\mathrm{T}}$ (Bryant et al., 1967; Boone, 1987); 3, M. oryzae DSM $11106^{\mathrm{T}}$ (Joulian et al., 2000); 4, M. beijingense DSM $15999^{\mathrm{T}}$ (Ma et al., 2005); 5, M. congolense DSM 7095 ${ }^{\mathrm{T}}$ (Cuzin et al., 2001); 6, M. alcaliphilum DSM 3387 ${ }^{\mathrm{T}}$ (Worakit et al., 1986); 7, M. subterraneum DSM $11074^{\mathrm{T}}$ (Kotelnikova et al., 1998); 8, M. formicicum DSM $1535^{\mathrm{T}}$ (Bryant \& Boone, 1987); 9, M. palustre DSM 3108 ${ }^{\mathrm{T}}$ (Zellner et al., 1989); 10, M. aarhusense DSM $15219^{\mathrm{T}}$ (Shlimon et al., 2004). Cells of all strains are rods. ND, No data available.

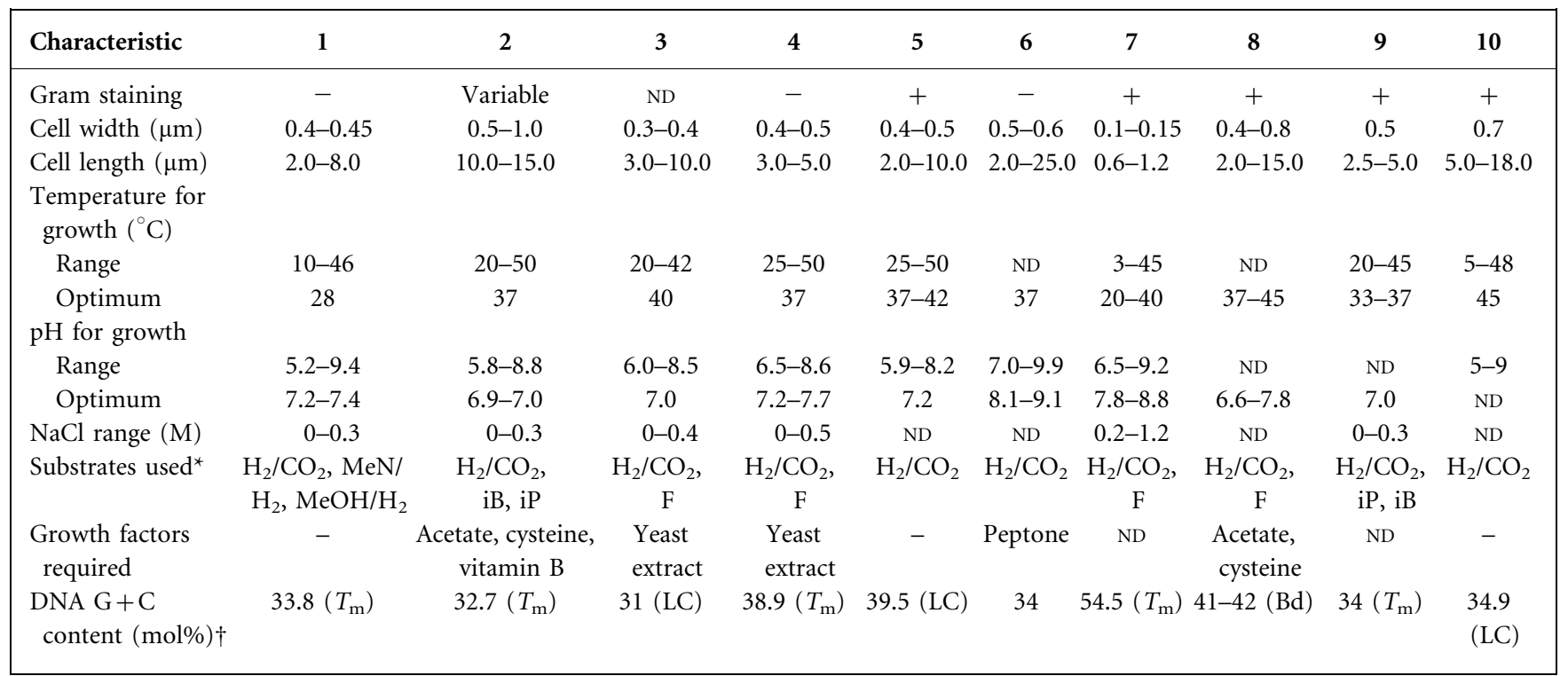

${ }^{\star}$ F, Formate; iB, isobutanol; iP, isopropanol; MeN, methylamine; $\mathrm{MeOH}$, methanol.

$\dagger$ Determined by buoyant density analysis (Bd), HPLC analysis (LC) or melting point analysis ( $\left.T_{\mathrm{m}}\right)$. 
Gram-negative-staining, non-motile, non-spore-forming, anaerobic, chemoautotrophic rods. Cells are slightly crooked, $2.0-8.0 \mu \mathrm{m}$ long and $0.40-0.45 \mu \mathrm{m}$ wide, occur singly or in chains (up to $30 \mu \mathrm{m}$ long) and show epifluorescence at $420 \mathrm{~nm}$. Cells divide through septum formation. Uses $\mathrm{H}_{2}$ plus $\mathrm{CO}_{2}$, methanol plus $\mathrm{H}_{2}$ and methylamine plus $\mathrm{H}_{2}$ as sources for growth and methane production. It does not grow on formate, acetate, ethanol, isopropanol, isobutanol, methylamine or trimethylamine. Growth is stimulated by acetate. Optimum growth conditions are $28{ }^{\circ} \mathrm{C}, \mathrm{pH} 7.0-7.2$ and $0.05 \mathrm{M} \mathrm{NaCl}$. The $\mathrm{G}+\mathrm{C}$ content of the DNA of the type strain is $33.8 \pm 0.3 \mathrm{~mol} \%$.

The type strain, $\mathrm{MK}^{\mathrm{T}}\left(=\mathrm{DSM} 19849^{\mathrm{T}}=\mathrm{VKM} \mathrm{B}-2440^{\mathrm{T}}\right)$, was isolated from ancient (3 million years old) permafrost sediments from the Kolyma lowland, Russia $\left(70^{\circ} 06^{\prime} \mathrm{N}\right.$ $\left.154^{\circ} 04^{\prime} \mathrm{E}\right)$.

\section{Acknowledgements}

We thank Dr Nataliya Suzina (Institute of Biochemistry and Physiology of Microorganisms RAS, Pushchino, Russia) for help with the electron micrographs and $\mathrm{Dr}$ Anatoliy Lysenko (Winogradsky Institute of Microbiology, Moscow, Russia) for determination of $\mathrm{G}+\mathrm{C}$ content. We are grateful to Dr Jean Euzéby for suggesting the species name. This work was supported by RFBR grants 08-05-00268 and 08-04-01004.

\section{References}

Balch, W. E., Fox, G. E., Magrum, L. J. \& Wolfe, R. S. (1979). Methanogens: reevalution of a unique biological group. Microbiol Rev 43, 260-296.

Boone, D. R. (1987). Replacement of the type strain of Methanobacterium formicicum and reinstatement of Methanobacterium bryantii sp. nov., nom. rev. (ex Balch and Wolfe 1981) with M.o.H. (DSM 863) as the type strain. Int J Syst Bacteriol 37, 172173.

Boone, D. R. \& Whitman, W. B. (1988). Proposal of minimal standards for describing new taxa of methanogenic bacteria. Int J Syst Bacteriol 38, 212-219.

Bryant, M. P. \& Boone, D. R. (1987). Isolation and characterization of Methanobacterium formicicum MF. Int J Syst Bacteriol 37, 171.

Bryant, M. P., Wolin, E. A., Wolin, M. J. \& Wolfe, R. S. (1967). Methanobacillus omelianskii, a symbiotic association of two species of bacteria. Arch Mikrobiol 59, 20-31.

Corradi, C., Kolle, O., Walter, K., Zimov, S. A. \& Schulze, E.-D. (2005). Carbon dioxide and methane exchange of a north-east Siberian tussock tundra. Glob Chang Biol 11, 1910-1925.

Cuzin, N., Ouattara, A. S., Labat, M. \& Garcia, J.-L. (2001). Methanobacterium congolense sp. nov., from a methanogenic fermentation of cassava peel. Int J Syst Evol Microbiol 51, 489-493.

De Ley, J., Cattoir, H. \& Reynaerts, A. (1970). The quantitative measurement of DNA hybridization from renaturation rates. Eur $J$ Biochem 12, 133-142.

Felsenstein, J. (1985). Confidence limits on phylogenies: an approach using the bootstrap. Evolution 39, 783-791.

Franzmann, P. D., Springer, N., Ludwig, W., Conway de Macario, E. \& Rohde, M. (1992). A methanogenic archaeon from Ace Lake,
Antarctica - Methanococcoides burtonii sp. nov. Syst Appl Microbiol 15, 573-581.

Franzmann, P. D., Liu, Y., Balkwill, D. L., Aldrich, H. C., Conway de Macario, E. \& Boone, D. R. (1997). Methanogenium frigidum sp. nov., a psychrophilic, $\mathrm{H}_{2}$-using methanogen from Ace Lake, Antarctica. Int J Syst Bacteriol 47, 1068-1072.

Gilichinsky, D., Khlebnikova, G., Zvyagintsev, D., FyodorovDavydov, D. \& Kudryavtseva, N. (1989). Microbiology of sedimentary materials in the permafrost zone. Int Geol Rev 31, 847-858.

Hungate, R. E. (1969). A roll tube method for cultivation of strict anaerobes. Methods Microbiol 3B, 117-132.

Joulian, C., Patel, B. K. C., Ollivier, B., Garcia, J.-L. \& Roger, P. A. (2000). Methanobacterium oryzae sp. nov., a novel methanogenic rod isolated from a Philippines ricefield. Int J Syst Evol Microbiol 50, 525528.

Kotelnikova, S. V., Obraztsova, A. Ya., Gongadze, G. M. \& Laurinavichius, K. S. (1993). Methanobacterium thermoflexum sp. nov. and Methanobacterium defluvii sp. nov.: thermophilic rodshaped methanogens isolated from anaerobic digester sludge. Syst Appl Microbiol 16, 427-435.

Kotelnikova, S., Macario, A. J. L. \& Pedersen, K. (1998). Methanobacterium subterraneum sp. nov., a new alkaliphilic, eurythermic and halotolerant methanogen isolated from deep granitic groundwater. Int J Syst Bacteriol 48, 357-367.

Lomans, B. P., Maas, R., Luderer, R., Op den Camp, H. J. M., Pol, A., van der Drift, C. \& Vogels, G. D. (1999). Isolation and characterization of Methanomethylovorans hollandica gen. nov., sp. nov., isolated from freshwater sediment, a methylotrophic methanogen able to grow on dimethyl sulfide and methanethiol. Appl Environ Microbiol 65, 36413650.

Ma, K., Liu, X. \& Dong, X. (2005). Methanobacterium beijingense sp. nov., a novel methanogen isolated from anaerobic digesters. Int J Syst Evol Microbiol 55, 325-329.

Morita, R. Y. (1975). Psychrophilic bacteria. Bacteriol Rev 39, 144-167.

Müller, V., Blaut, M. \& Gottschalk, G. (1986). Utilization of methanol plus hydrogen by Methanosarcina barkeri for methanogenesis and growth. Appl Environ Microbiol 52, 269-274.

Powell, G. E. (1983). Interpreting gas kinetics of batch culture. Biotechnol Lett 5, 437-440.

Rivkina, E., Gilichinsky, D., Wagener, S., Tiedje, J. \& McGrath, J. (1998). Biogeochemical activity of anaerobic microorganisms from buried permafrost sediments. Geomicrobiol J 15, 187-193.

Rivkina, E., Gilichinsky, D., McKay, C. \& Dallimore, S. (2001). Methane distribution in permafrost: evidence for an interpore pressure methane hydrate. In Permafrost Response on Economic Development, Environmental Security and Natural Resources, pp. 487-497. Edited by R. Paepe \& V. P. Melnikov. Dordrecht: Kluwer Academic.

Rivkina, E., Shcherbakova, V., Laurinavichuis, K., Petrovskaya, L., Krivushin, K., Kraev, G., Pecheritsina, S. \& Gilichinsky, D. (2007). Biogeochemistry of methane and methanogenic archaea in permafrost. FEMS Microbiol Ecol 61, 1-15.

Saitou, N. \& Nei, M. (1987). The neighbor-joining method: a new method for reconstructing phylogenetic trees. Mol Biol Evol 4, 406-425.

Sambrook, J., Fritsch, E. F. \& Maniatis, T. (1989). Molecular Cloning: a Laboratory Manual, 2nd edn. Cold Spring Harbor, NY: Cold Spring Harbor Laboratory.

Schirrmeister, L., Siegert, C., Kuznetsova, T., Kuzmina, S., Andreev, A., Kienast, F., Meyer, H. \& Bobrov, A. A. (2002). Paleoenvironmental and paleoclimatic records from permafrost deposits in the Arctic region of Northern Siberia. Quat Int 89, 97-118. 
Shcherbakova, V. A., Chyvilskya, N. A., Rivkina, E. M., Pecheritsyna, S. A., Laurinavichius, K. S., Suzina, N. E., Osipov, Yu. A., Lysenko, A. M., Gilichinsky, D. A. \& Akimenko, V. K. (2005). Novel psychrophilic anaerobic spore-forming bacterium from the overcooled water brine in permafrost: description Clostridium algoriphilum sp. nov. Extremophiles 9, 239-246.

Sher, A. V. (1974). Pleistocene mammals and stratigraphy of the Far Northeast USSR and North America. Int Geol Rev 16, 1-284.

Sher, A. V. (1997). A brief overview of the Late-Cenozoic history of the Western Beringian lowlands. In Terrestrial Paleoenvironmental Studies in Beringia, pp. 3-6. Edited by M. E. Edwards, A. V. Sher \& R. D. Guthrie. Fairbanks, AK: University of Alaska Museum.

Sher, A. V., Kuzmina, S. A., Kuznetsova, T. V. \& Sulerzhitsky, L. D. (2005). New insights into the Weichselian environment and climate of the East Siberian Arctic, derived from fossil insects, plants, and mammals. Quat Sci Rev 24, 533-569.

Shi, T., Reeves, R. H., Gilichinsky, D. A. \& Friedmann, E. I. (1997). Characterization of viable bacteria from Siberian permafrost by $16 \mathrm{~S}$ rDNA sequencing. Microb Ecol 33, 169-179.

Shlimon, A. G., Friedrich, M. W., Niemann, H., Ramsing, N. B. \& Finster, K. (2004). Methanobacterium aarhusense sp. nov., a novel methanogen isolated from a marine sediment (Aarhus Bay, Denmark). Int J Syst Evol Microbiol 54, 759-763.

Tamura, K., Nei, M. \& Kumar, S. (2004). Prospects for inferring very large phylogenies by using the neighbor-joining method. Proc Natl Acad Sci U S A 101, 11030-11035.

Tamura, K., Dudley, J., Nei, M. \& Kumar, S. (2007). MEGA4: molecular evolutionary genetics analysis (MEGA) software version 4.0. Mol Biol Evol 24, 1596-1599.

Vatsurina, A., Badrutdinova, D., Schumann, P., Spring, S. \& Vainshtein, M. (2008). Desulfosporosinus hippei sp. nov., a mesophilic sulfate-reducing bacterium isolated from permafrost. Int J Syst Evol Microbiol 58, 1228-1232.
Virina, E. I. (1997). Paleomagnetic stratigraphy of Pliocene/Pleistocene sediments of the Kolyma lowland and some problems of correlation with the Alaska record. In Terrestrial Paleoenvironmental Studies in Beringia, pp. 19-24. Edited by M. E. Edwards, A. V. Sher \& R. D. Guthrie. Fairbanks, AK: University of Alaska Museum.

Vishnivetskaya, T., Kathariou, S., McGrath, J., Gilichinsky, D. \& Tiedje, J. (2000). Low-temperature recovery strategies for the isolation of bacteria from ancient permafrost sediments. Extremophiles 3, 165-173.

Vorobyova, E., Soina, V., Gorlenko, M., Minkovskaya, N., Mamukelashvili, A., Zalinova, N., Gilichinsky, D., Rivkina, E. \& Vishnivetskaya, T. (1997). The deep cold biosphere: facts and hypothesis. FEMS Microbiol Rev 20, 277-290.

Worakit, S., Boone, D. R., Mah, R. A., Abdel-Samie, M.-E. \& ElHalwagi, M. M. (1986). Methanobacterium alcaliphilum sp. nov., an $\mathrm{H}_{2}$-utilizing methanogen that grows at high $\mathrm{pH}$ values. Int $J$ Syst Bacteriol 36, 380-382.

Zazhigin, V. S. (1997). Late-Pliocene and Pleistocene rodent faunas in the Kolyma lowland: possible correlations with North America. In Terrestrial Paleoenvironmental Studies in Beringia, pp. 25-29. Edited by M. E. Edwards, A. V. Sher \& R. D. Guthrie. Fairbanks, AK: University of Alaska Museum.

Zellner, G. \& Winter, J. (1987). Secondary alcohols as hydrogen donors for $\mathrm{CO}_{2}$-reduction by methanogens. FEMS Microbiol Lett 44, 323-328.

Zellner, G., Bleicher, K., Braun, E., Kneifel, H., Tindall, B. J., Conway de Macario, E. \& Winter, J. (1989). Characterization of a new mesophilic, secondary alcohol-utilizing methanogen, Methanobacterium palustre spec. nov. from a peat bog. Arch Microbiol 151, 1-9.

Zvyagintsev, D. G., Gilichinsky, D. A., Blagodatsky, S. A., Vorobyova, E. A., Khlebnikova, G. M., Arkhangelov, A. A. \& Kudryavtseva, N. N. (1985). The time of microbial preservation in constantly frozen sedimentary rocks and buried soils. Mikrobiologiia 54, 155-163 (in Russian). 